wirken zu wollen, daß die Nachahmungen für Fruchtpasten, besonders die Agarerzeugnisse, unter entsprechenden Bezeichnungen, wie z. B. „Künstliche Pasten“, vielleicht noch mit Angabe des Geschmackes, wie "mit Erdbeergeschmack", in den Handel kommen und feilgehalten werden.

\title{
Über das Kupfersulfat-Serum der Milch nach H. Lythgoe.
} Von

\author{
Edwin Ackermann und Charles Valencien. \\ Mitteilung aus dem Kantonalen Laboratorium in Genf.
}

[Eingegangen am 19. September 1912.]

Durch ein Referat in dieser Zeitschrift ${ }^{1}$ ) erhielten wir Kenntnis von einer Veröffentlichung von $\mathrm{Hermann}$ C. Lythgoe ${ }^{2}$ ) über verschiedene Darstellungsweisen des Milchserums zum Zwecke der refraktometrischen Untersuchung. In dieser Veröffentlichung wird unter anderem die Methode der Untersuchung des ChlorcalciumSerums einer Kritik unterworfen. Leider ist es heute noch nicht zur Regel geworden, wenn ein Autor die Methode eines Kollegen beurteilt, diesem Kenntnis von der Kritik zu geben. Da uns die Originalarbeit nicht zur Verfügung steht, so sehen wir uns genötigt, auf Grund des erwähnten Referates 4 Jahre nach dem Erscheinen der Arbeit auf diese zu antworten.

Lythgoe schlägt folgendes Verfahren zur Darstellung des Milchserums für die refraktometrische Prüfung der Miloh vor: $40 \mathrm{ccm}$ Milch werden mit $10 \mathrm{~cm}$ einer Kupfersulfatlösung von $72,5 \mathrm{~g}$ im Liter versetzt, einige Minuten stehen gelassen und filtriert; wenn das Filtrat etwas trübe ist, so wird es von neuem auf das Filter gegossen und das klare Serum direkt refraktometrisch geprüft. L y th g o e gibt an, daß die Kupfersulfatlösung bei $20^{\circ}$ ein Lichtbrechungsvermögen von 36,0 (Eintauchrefraktometer) besitzt.

Das nach dieser Vorschrift mit verschiedenen Milchproben von uns hergestellte Serum war klar und konnte sehr genau refraktometrisch geprüft werden.

Um die Empfindlichkeit der Methode in bezug auf den Wasserzusatz zur Milch zu prüfen, haben wir Milch mittlerer Zusammensetzung in steigenden Mengen mit Wasser versetzt, die Seren sowohl mit Chlorcalcium als auch mit Kupfersulfat dargestellt und das Brechungsvermögen bestimmt. Unsere Kupfersulfatlösung von $72,5 \mathrm{~g}$ Kuptersulfat im Liter ergab bei $20^{\circ}$ eine Refraktometerzahl von 36,0 und bei $17,5^{\circ}$ eine solche von 36,7 , was übrigens auch mit den Tabellen von $\mathbf{B}$. W a g n er übereinstimmt. Unsere Untersuchungsergebnisse waren folgende:

1) Diese Zeitschrift 1912, 23, 533.

2) Rep. Food and Drug Insp. Massachusets 1908, 37-38. 


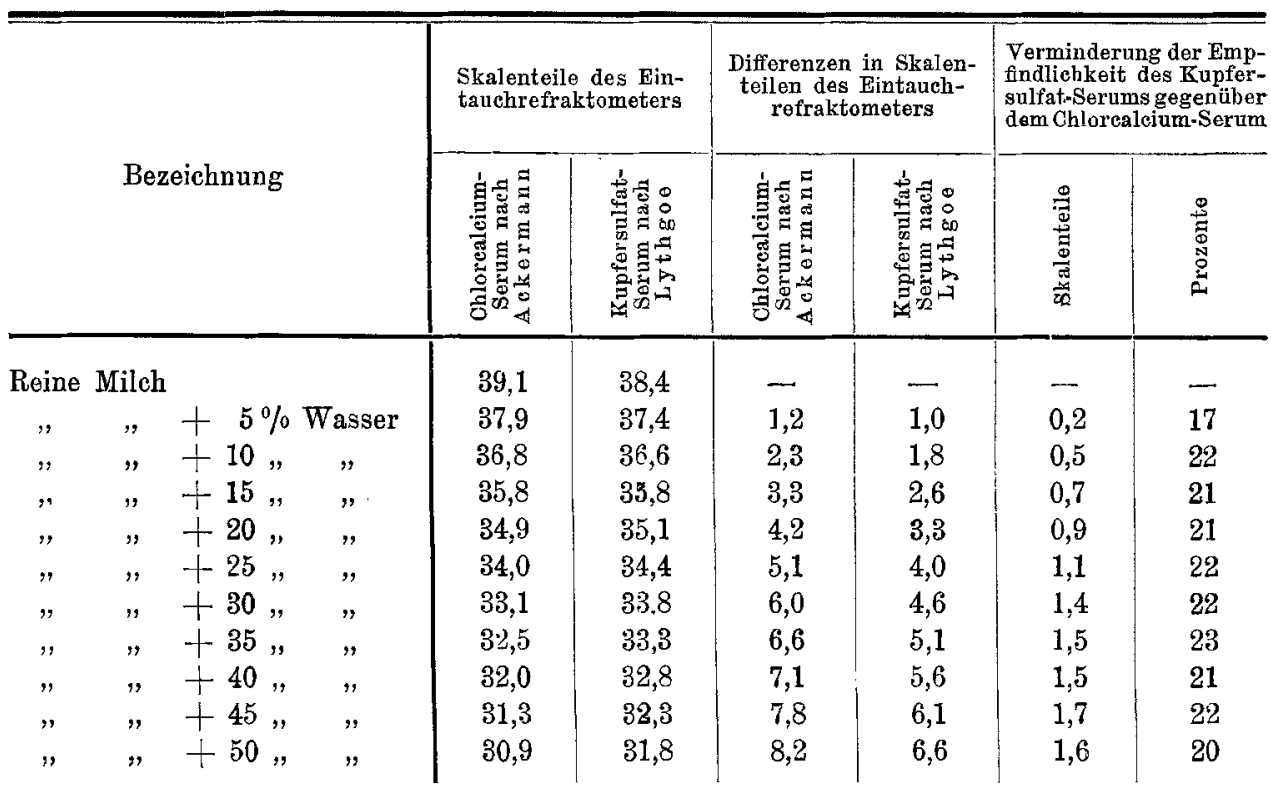

Der Hauptmangel des Kupfersulfatserums liegt darin, daßo durch den Zusatz des Fällungsmittels eine starke Verdünnung des Milchserums stattfindet, wodurch die Empfindlichkeit der refraktometrischen Prüfungen bei Wasserzusatz nicht unbedeutend herabgesetzt wird. Aus demselben Grunde hat der eine von uns ${ }^{1}$ ) die Verwendung des B a i e r'schen Asaprolserums verworfen.

Für die verschiedenen Darstellungsweisen der Milchseren ergeben sich folgende Verdünnungen durch den Zusatz des Fällungsmittels:

\begin{tabular}{|c|c|c|c|c|c|c|}
\hline $\mathrm{cem}$ & Milch & + & $\mathrm{ccm}$ & Asaprollösung & $100 \%$ & Verdünnung \\
\hline & $"$ & + & & Kupfersulfatlösung & 25, & $"$ \\
\hline & $"$ & $+0,25$ & & Chlorcalciumlösung & 0,83 & '" \\
\hline
\end{tabular}

Dieser Einfluß wird auch durch folgendes dargetan:

$40 \mathrm{ccm}$ Wasser $+10 \mathrm{ccm}$ Kupfersulfatlösung $=19,6$ Refraktionswert

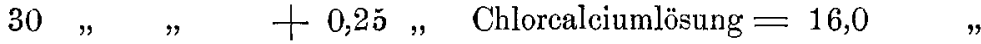

Wir kommen für die von Lythgoe vorgeschlagene Methode zu folgenden Schlüssen :

Vorteil: Die Darstellung des Serums geschieht rasch auf kaltem Wege, und man erhält ein sehr klares Serum.

Nachteil: Die Filtration ist nötig, und durch das Fällungsmittel wird die Empfindlichkeit des refraktometrischen Verfahrens für den Nachweis des Wasserzusatzes bedeutend vermindert.

Die Kupfersulfat-Methode bedeutet also gegenüber der Verwendung von Chlorcalcium nicht nur keinen Fortschritt, sondern einen Rückschritt.

Wenn nun Lythgoe behauptet, daß man mit Chlorcalcium kein klares Serum erbält, das eine genaue Bestimmung des Lichtbrechungsvermögens erlaubt, so steht er damit im Widerspruche mit zablreichen Chemikern, die täglich dieses

$\left.{ }^{1}\right)$ Diese Zeitschrift 1908, 16, 586. 
Serum herstellen und genaue Ergebnisse erhalten. Nehmen wir auch nur an, daß infolge der leichten Trübung, ${ }^{1 / 10^{\circ}}$ Differenz in der Ablesung vorkommt, so muß man sich sagen, was ist dies im Vergleich zur Verminderung der Empfindlichleit des Lichtbrechungsvermögens, die bei einem Wasserzusatz von $20 \%$ fast einen ganzen Grad ausmacht.

Betreffs der schwierigen Ablesung der Refraktionswerte möchten wir übrigens auf folgenden Passus einer früheren Arbeit hinweisen. In einer Veröffentlichung ${ }^{1}$ ) über das spezifische Gewicht des Chlorcalcium-Serums sagten wir: „Das Serum kann abgegossen und direkt refraktometrisch geprüft werden, wogegen für pyknometrische Bestimmungen eine Filtration durch dünnes Filtrierpapier nötig ist, um kleine Flocken zu entfernen und zu verhindern, daß das genaue Einstellen im Pyknometer durch das fettige Häutchen, das immer oben aufschwimmt, gestört wird".

Dieses fettige Häutchen kann aber auch bei der refraktometrischen Messung störend einwirken; es wird oft beim Eintauchen des Refraktometers von der Fläche des.Prismas angenommen und kann so ein richtiges Benetzen des Prismas verhindern. In solchen Fällen erhält man ein trübes Bild und die Grenzlinie erscheint verschwommen. Es genügt in diesen Fällen nun, das Refraktometer aus dem Serum heraus zu heben, mit dem Daumen die Prismafläche abzuwischen und rasch wieder einzutauchen. Man erhält dann ein klares Bild und eine scharfe Grenzlinie.

1) Mitteilg. a. d. Gebiete d. Lebensm.-Unters. u. Hygiene, herausgeg. v. Schweizer. Gesundh.-Amt 1910, 1, 268.

\section{Ergebnisse der Untersuchung von Heilmitteln, Geheim- mitteln, kosmetischen und ähnlichen Mitteln.}

Von

\section{Griebel.}

Mitteilung aus der Statlichen Nahrungsmittel-Untersuchungsanstalt für die im Landespolizeibezirk Berlin bestehenden Königlichen Polizeiverwaltungen.

[Eingegangen am 29. September 1912.]

Im Anschluß an die früher in dieser Zeitschrift erschienenen Mitteilungen ${ }^{1}$ ) folgt nachstehend ein weiterer kurzer Auszug aus den Ergebnissen der in der Staatlichen Nahrungsmittel-Untersuchungsanstalt ausgeführten Untersuchungen auf dem genannten Gebiet. Von der Aufführung der zahlreichen Menstruationsmittel ist hierbei, soweit sie lediglich aus Destillaten oder aus Kamillenpulver bestanden, Abstand genommen worden.

371. Heilmittel gegen Gonorrhöe, von Apotheker Kaesbach in Zaborze, setzte sich aus einer innerlich und einer äußerlich anzuwendenden Flüssigkeit zusammen. Erstere war eine aus Sandelöl, fettem Öl, Glycerin, Traganth und Wasser hergestellte Emulsion. Preis einer $100 \mathrm{ccm}$ fassenden Flasche $=3,50 \mathrm{Mk}$.

1) Vergl. diese Zeitschrift 1907, 14, 498-499; 1909, 17, 79-86; 18,655-661; 1910, 20, 500-505; 1911, 21, 748-753. 